\title{
Synthesis, Crystal Structure, Hydrogen Bonding and Thermal Behaviour of a Three-Dimensional Cu(II)-benzene-1,2,4,5-tetracarboxylate Templated by 1,9-Diaminononane
}

\author{
Roberto Köferstein and Christian Robl
}

Z. Anorg. Allg. Chem. 640 (2014) 1937-1942.

DOI: 10.1002/zaac.201400177

\begin{abstract}
Triclinic single crystals of $\mathrm{Cu}_{4}\left(\mathrm{H}_{3} \mathrm{~N}-\left(\mathrm{CH}_{2}\right)_{9}-\mathrm{NH}_{3}\right)(\mathrm{OH})_{2}\left[\mathrm{C}_{6} \mathrm{H}_{2}(\mathrm{COO})_{4}\right]_{2} \cdot 5 \mathrm{H}_{2} \mathrm{O}$ were prepared in aqueous solution at $80{ }^{\circ} \mathrm{C}$ in the presence of 1,9-diaminononane. Space group $P \overline{1}$ (no. 2) with $a=1057.5(2), b=1166.0(2), c=1576.7(2) \mathrm{pm}, \alpha=106.080(10)^{\circ}, \beta=90.73(2)^{\circ}$ and $\gamma=$ $94.050(10)^{\circ}$. The four crystallographic independent $\mathrm{Cu}^{2+}$ ions are surrounded by five oxygen atoms each with $\mathrm{Cu}-\mathrm{O}$ distances between 191.4(3) and 231.7(4) pm. The connection between the $\mathrm{Cu}^{2+}$ coordination polyhedra and the $\left[\mathrm{C}_{6} \mathrm{H}_{2}(\mathrm{COO})_{4}\right]^{4-}$ anions yields three-dimensional framework with negative excess charge and wide centrosymmetric channel-like voids. These voids extend parallel to [001] with the diagonal of the nearly rectangular cross-section of approximately $900 \mathrm{pm}$. The channels of the framework accommodate $\left[\mathrm{H}_{3} \mathrm{~N}-\left(\mathrm{CH}_{2}\right)_{9}-\mathrm{NH}_{3}\right]^{2+}$ cations and water molecules, which are not connected to $\mathrm{Cu}^{2+}$. The nonane-1,9-diammonium cations adopt a partial gauche conformation. Thermoanalytical measurements in air show a loss of water of crystallization starting at $90{ }^{\circ} \mathrm{C}$ and finishing at approx. $170{ }^{\circ} \mathrm{C}$. The dehydrated compound is stable up to $260{ }^{\circ} \mathrm{C}$ followed by an exothermic decomposition yielding copper oxide.
\end{abstract}
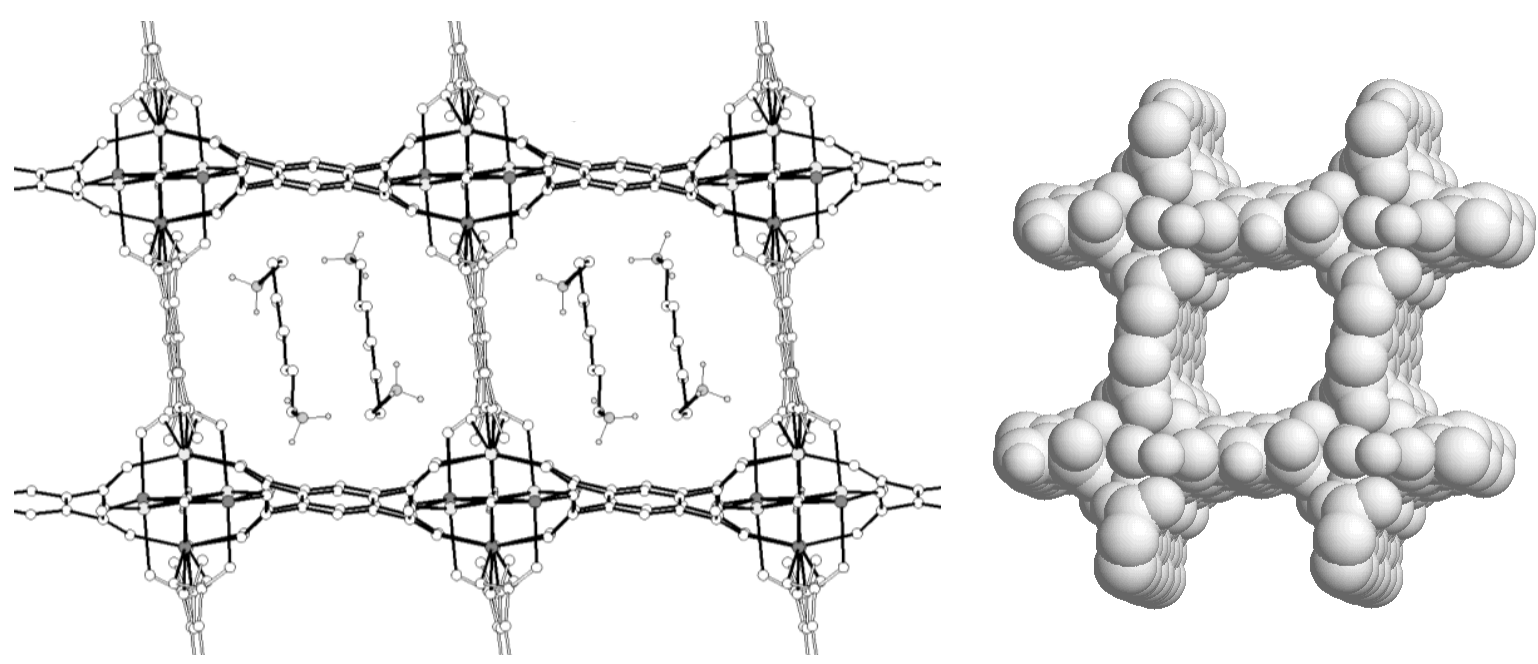


\title{
Synthesis, Crystal Structure, Hydrogen Bonding and Thermal Behaviour of a Three-Dimensional
}

\author{
Cu(II)-benzene-1,2,4,5-tetracarboxylate Templated by 1,9-Diaminononane
}

\author{
Roberto Köferstein $^{[\mathrm{a}, \mathrm{b}]}$ and Christian Robl ${ }^{*[a]}$
}

Dedicated to Professor Dr. Volker Woest on the Occasion of His 60th Birthday.

Keywords: Benzene-1,2,4,5-tetracarboxylate; Metal-organic-framework, Crystal structure; Template synthesis; Diaminononane

\begin{abstract}
Triclinic single crystals of $\mathrm{Cu}_{4}\left(\mathrm{H}_{3} \mathrm{~N}-\left(\mathrm{CH}_{2}\right)_{9^{-}}\right.$ $\left.\mathrm{NH}_{3}\right)(\mathrm{OH})_{2}\left[\mathrm{C}_{6} \mathrm{H}_{2}(\mathrm{COO})_{4}\right]_{2} \cdot 5 \mathrm{H}_{2} \mathrm{O}$ have been prepared in aqueous solution at $80{ }^{\circ} \mathrm{C}$ in the presence of 1,9-diaminononane. Space group $P-1$ (no. 2) with $a=1057.5(2), b=1166.0(2), c=1576.7(2)$ pm, $\alpha=106.080(10)^{\circ}, \beta=90.73(2)^{\circ}$ and $\gamma=94.050(10)^{\circ}$. The four crystallographic independent $\mathrm{Cu}^{2+}$ ions are surrounded by five oxygen atoms each with $\mathrm{Cu}-\mathrm{O}$ distances between 191.4(3) and 231.7(4) pm. The connection between the $\mathrm{Cu}^{2+}$ coordination polyhedra and the $\left[\mathrm{C}_{6} \mathrm{H}_{2}(\mathrm{COO})_{4}\right]^{4-}$ anions leads to a threedimensional framework with negative excess charge and wide

These voids extend parallel to [001] with the diagonal of the nearly rectangular crossection of approximately $900 \mathrm{pm}$. The channels of the framework accommodate $\left[\mathrm{H}_{3} \mathrm{~N}-\left(\mathrm{CH}_{2}\right)_{9}-\mathrm{NH}_{3}\right]^{2+}$ cations and water molecules, which are not connected to $\mathrm{Cu}^{2+}$. The nonane-1,9-diammonium-cations adopt a partial gauche conformation. Thermoanalytical measurements in air show a loss of water of crystallization starting at $90{ }^{\circ} \mathrm{C}$ and finishing at approx. $170{ }^{\circ} \mathrm{C}$. The dehydrated compound is stable up to $260{ }^{\circ} \mathrm{C}$ followed by an exothermic decomposition yielding copper oxide.
\end{abstract} centrosymmetric channel-like voids.

* Corresponding Author

Fax: +49-3641-948152

E-Mail: crr@uni-jena.de

[a] Institute of Inorganic and Analytical Chemistry, Friedrich-

Schiller-University Jena,

Humboldtstrasse 8,

07743 Jena, Germany

[b] Institute of Chemistry, Inorganic Chemistry, Martin-LutherUniversity Halle-Wittenberg,

Kurt-Mothes-Strasse 2,

06120 Halle, Germany

\section{Introduction}

Multi-dentate complexing agents are very well suited to form coordination polymers with various structural features, if they are linked to suitable metal cations [1-12]. The carboxylate groups of benzenecarboxylic acids anions are able to coordinate metal ions in flexible modes. In particular the coordination between the anions of benzene-1,2,4,5carboxylic acid (pyromellitic acid) and metal cations leads to coordination polymers with chain- and layer-like structures as well as to three-dimensional frameworks (socalled MOF's) [13-17]. The structures of such coordination polymers can be varied using rational design synthesis e.g. $\mathrm{N}$-donor ligands as spacers and organic amines as template molecules, respectively [18-28]. In the presence of organic amines as template molecules three-dimensional frameworks are available [29-34]. Previous work on the reaction between $\mathrm{Cu}^{2+}$ and benzene-1,2,4,5-carboxylic acid in the presence of templating agents resulted in various three-dimensional frameworks with channel-like voids

resembling zeolite structures [35-41]. Moreover, $\mathrm{Cu}^{2+}$ benzenecarboxylato complexes show interesting magnetic properties [26,36,37,39,41,42] and they are suitable as catalysts for e.g. peroxidative oxidation processes, for hydroxylation and isomerisation reactions, as well as for the reduction of nitrite $[38,43-46]$.

We are interested in the influence of diamines with various chain-lengths as template agents on the structures of $\mathrm{Cu}^{2+}$-benzene-1,2,4,5-tetracarboxylato complexes. In previous work we used 1,4-diaminobutane [41] and 1,6diaminohexane [47] as templates. Here we report on the formation of a copper benzene-1,2,4,5-tetracarboxylate in the presence of 1,9-diaminononane.

\section{Results and Discussion}

In $\mathrm{Cu}_{4}\left(\mathrm{H}_{3} \mathrm{~N}-\left(\mathrm{CH}_{2}\right)_{9}-\mathrm{NH}_{3}\right)(\mathrm{OH})_{2}\left[\mathrm{C}_{6} \mathrm{H}_{2}(\mathrm{COO})_{4}\right]_{2} \cdot 5 \mathrm{H}_{2} \mathrm{O}$ there are four crystallographically independent $\mathrm{Cu}^{2+}$-ions occupying general positions of space group $\mathrm{P}-1 . \mathrm{Cu}(1)$ is coordinated in a distorted square pyramidal fashion by three carboxylate oxygen atoms $(\mathrm{O}(3), \mathrm{O}(6), \mathrm{O}(13))$ and twice by $\mathrm{O}(18)$ stemming from hydroxo groups. Two coordination polyhedra of $\mathrm{Cu}(1)$ correlated by a crystallographic inversion center are linked by a common edge $(2 \mathrm{x} \mathrm{O}(18))$ yielding a short $\mathrm{Cu}(1)-\mathrm{Cu}(1)$ contact of 292.27(12) pm. Mihalcea et al. [48] reported on similar bridging of metal centres by hydroxo groups in uranyl benzene-1,2,4,5tetracarboxylato complexes. The $\mathrm{Cu}(3)$ cation is surrounded in a distorted trigonal bipyramidal manner by four 
carboxylate oxygen atoms $(\mathrm{O}(4), \mathrm{O}(5), \mathrm{O}(9), \mathrm{O}(14))$ and one hydroxo oxygen atom $(\mathrm{O}(18)$, Tab. 1). $\mathrm{O}(18)$ is a common corner of the coordination polyhedra of $\mathrm{Cu}(1)$ and $\mathrm{Cu}(3)$ (Fig. 1). The $\mathrm{Cu}(2)$ and $\mathrm{Cu}(4)$ cations are surrounded in a similar manner and the polyhedra are bridged by common hydroxo groups $(2 \mathrm{x} \mathrm{O}(17))$ resulting in a $\mathrm{Cu}(2)-\mathrm{Cu}(2)$ contact of 294.89(13) pm. Employing the method of Trömel $[49,50]$ the bond order is calculated to $2.12(\mathrm{Cu}(1)), 2.12$ $(\mathrm{Cu}(2)), 1.94(\mathrm{Cu}(3))$, and $1.90(\mathrm{Cu}(4))$, respectively. Chiang et al. [51] reported on a similar hydroxo-bridged tetranuclear unit in a cobalt benzene-1,2,4,5-tetracarboxylate The $\mathrm{Cu}^{2+}$-benzene-1,2,4,5-tetracarboxylato complex templated by 1,6-diaminohexane [47] shows similar polyhedra. The apical positions $(\mathrm{O}(11), \mathrm{O}(13))$ of the $\mathrm{Cu}(1)$ and $\mathrm{Cu}(3)$ polyhedra, however, in the present compound are more remote obviously due to hydrogen bonds with uncoordinated water molecules (see Tab. 3).
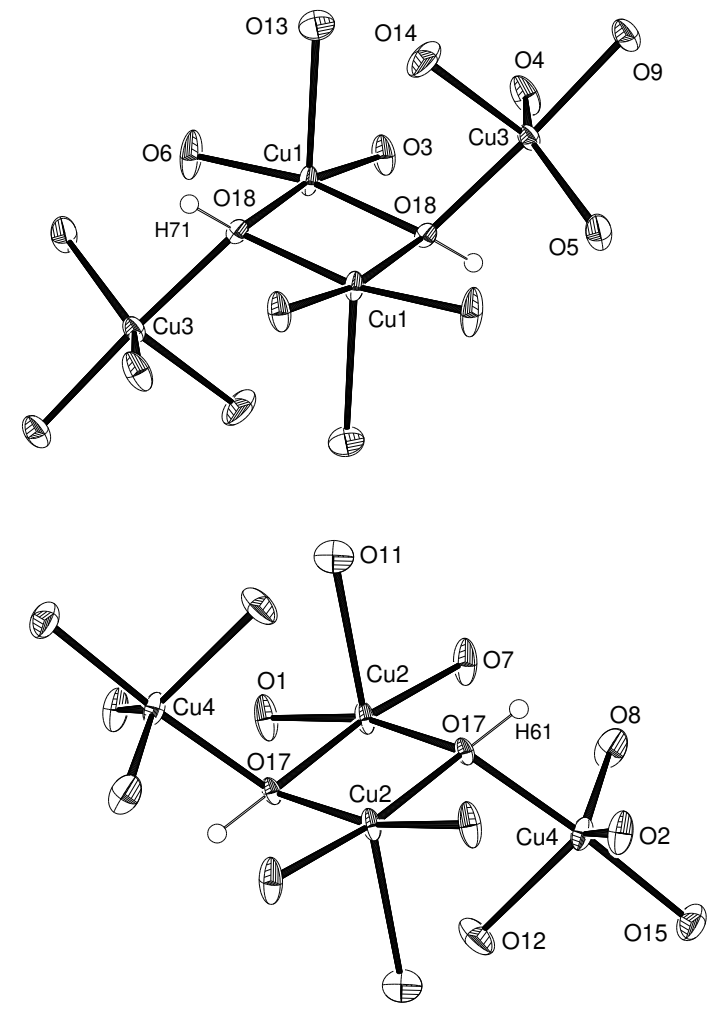

Figure 1. The coordination environments of $\mathrm{Cu}^{2+}$ (Ellipsoids are given at $50 \%$ probability, arbitrary radii for hydrogen atoms).

Table 1. The Coordination of $\mathrm{Cu}^{2+}$ in $\mathrm{Cu}_{4}\left(\mathrm{H}_{3} \mathrm{~N}-\left(\mathrm{CH}_{2}\right)_{9-}\right.$ $\left.\mathrm{NH}_{3}\right)(\mathrm{OH})_{2}\left[\mathrm{C}_{6} \mathrm{H}_{2}(\mathrm{COO})_{4}\right]_{2} \cdot 5 \mathrm{H}_{2} \mathrm{O}$

\begin{tabular}{|c|c|c|c|}
\hline \multicolumn{4}{|c|}{ bond lengths (pm) } \\
\hline $\mathrm{Cu}_{(1)}-\mathrm{O}_{(3)}$ & 193.1(3) & $\mathrm{Cu}_{(2)}-\mathrm{O}_{(1)}$ & 191.4(3) \\
\hline $\mathrm{Cu}_{(1)}-\mathrm{O}_{(18)}$ & $196.8(3)$ & $\mathrm{Cu}_{(2)}-\mathrm{O}_{(7)}$ & 194.6(4) \\
\hline $\mathrm{Cu}_{(1)}-\mathrm{O}_{(13)}$ & 229.1(4) & $\mathrm{Cu}_{(2)}-\mathrm{O}_{(11)}$ & 231.7(4) \\
\hline $\mathrm{Cu}_{(1)}-\mathrm{O}_{(6)}$ & $193.4(4)$ & $\mathrm{Cu}_{(2)}-\mathrm{O}_{(17)}$ & $194.0(3)$ \\
\hline $\mathrm{Cu}_{(1)}-\mathrm{O}_{(18)} \#$ & 194.3(3) & $\mathrm{Cu}_{(2)}-\mathrm{O}_{(17)}^{\# 1}$ & 197.1(3) \\
\hline $\mathrm{Cu}_{(1)} \cdots \mathrm{Cu}_{(1)}^{\#}$ & $292.27(12)$ & $\mathrm{Cu}_{(2)} \cdots \mathrm{Cu}_{(2)}^{\# 1}$ & $294.89(13)$ \\
\hline $\mathrm{Cu}_{(3)}-\mathrm{O}_{(18)}$ & $192.8(3)$ & $\mathrm{Cu}_{(4)}-\mathrm{O}_{(17)}$ & 192.3(3) \\
\hline $\mathrm{Cu}_{(3)}-\mathrm{O}_{(4)}$ & $202.7(4)$ & $\mathrm{Cu}_{(4)}-\mathrm{O}_{(2)}$ & 204.2(3) \\
\hline
\end{tabular}

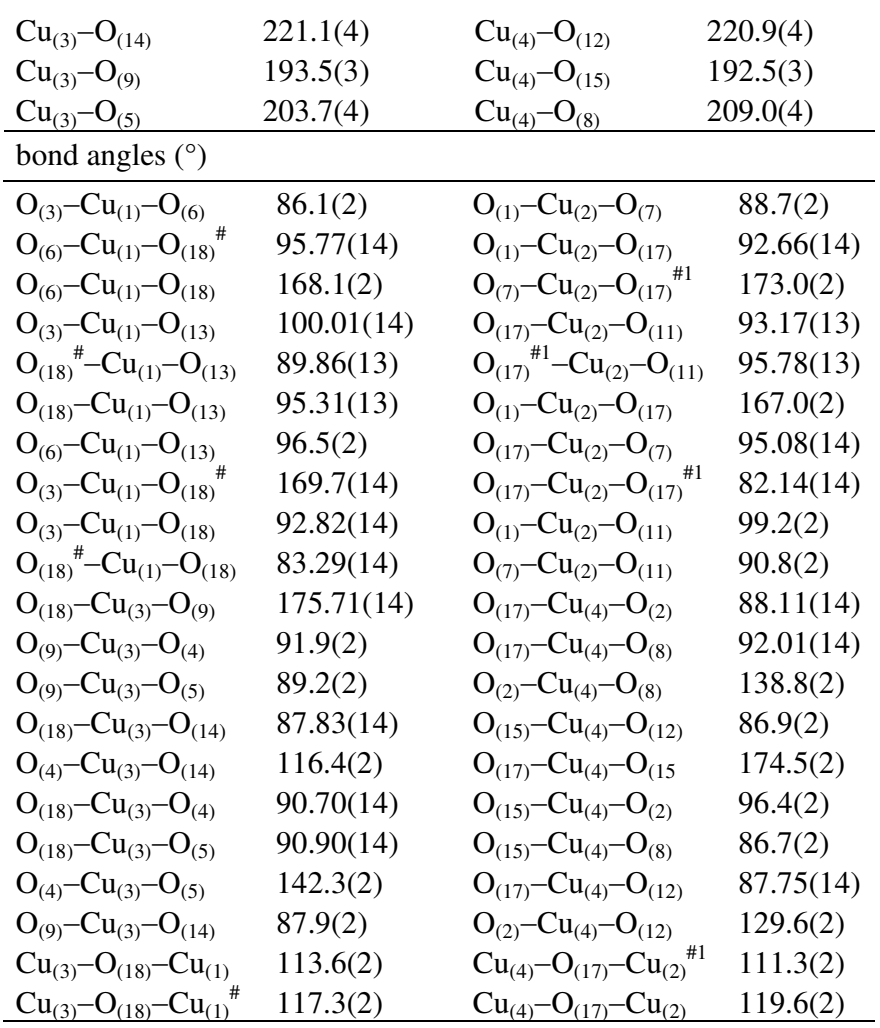

\#: -x;-y+1;-z+1 , \#1:-x;-y+1;-z

There are three crystallographically independent $\left[\mathrm{C}_{6} \mathrm{H}_{2}(\mathrm{COO})_{4}\right]^{4-}$ anions (see Fig. 2 and 3 ). The anion $\mathrm{I}$ is almost planar with respect to the carbon skeleton. The largest deviation from a plane fitted to the carbon atoms is $4.5 \mathrm{pm}(\mathrm{C}(15))$. The carboxylate groups are twisted against the $\mathrm{C}_{6}$-ring by $38.8^{\circ}\left((\mathrm{C}(16), \mathrm{O}(1), \mathrm{O}(2)), 56.0^{\circ}((\mathrm{C}(17)\right.$, $\mathrm{O}(3), \mathrm{O}(4)), 36.1^{\circ}\left((\mathrm{C}(18), \mathrm{O}(5), \mathrm{O}(6))\right.$, and $55.8^{\circ}(\mathrm{C}(19)$, $\mathrm{O}(7), \mathrm{O}(8))$, respectively. The $\mathrm{C}-\mathrm{O}$ bond lengths range from $123.6(6)$ to $127.0(6) \mathrm{pm}$ (Tab. 2). All oxygen atoms from this anion are involved in the $\mathrm{Cu}^{2+}$ coordination. The carbon skeletons of the centrosymmetric anions II and III are also planar with a largest out of plane deviation of $5.42 \mathrm{pm}$ (C(22)) for anion II and $3.96 \mathrm{pm}(\mathrm{C}(27))$ for anion III. The carboxylate groups show torsion angles of $26.4(\mathrm{C}(23), \mathrm{O}(9)$, $\mathrm{O}(10)$ ) and $65.1^{\circ}(\mathrm{C}(24), \mathrm{O}(11), \mathrm{O}(12))$ for anion II as well as $70.2^{\circ}(\mathrm{C}(28), \mathrm{O}(13), \mathrm{O}(14))$ and $22.6^{\circ}(\mathrm{C}(29), \mathrm{O}(15)$, $\mathrm{O}(16))$ for anion III with respect to the $\mathrm{C}_{6}$-ring. The $\mathrm{C}-\mathrm{O}$ bond lengths range from 122.1(6) to $129.4(6) \mathrm{pm}$. The shortest $\mathrm{C}-\mathrm{O}$ bonds are formed by $\mathrm{O}(16)$ and $\mathrm{O}(10)$ which are not connected to $\mathrm{Cu}^{2+}$. 


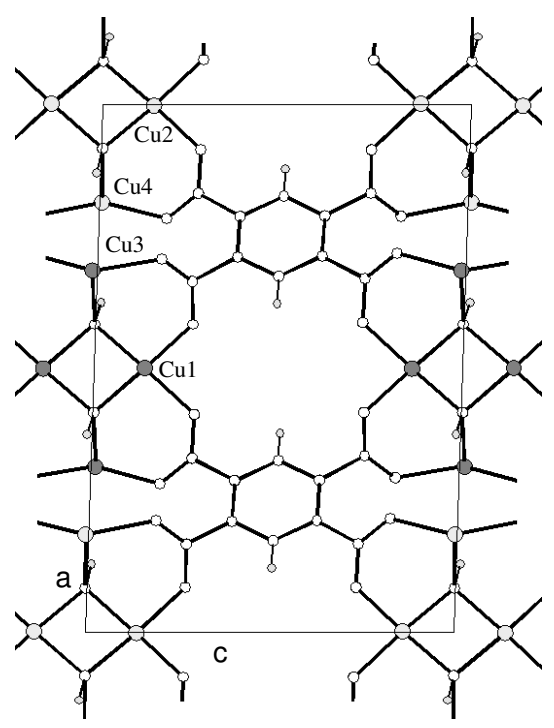

Figure 2. The connection between anion $\mathrm{I}$ and $\mathrm{Cu}^{2+}$-cations.

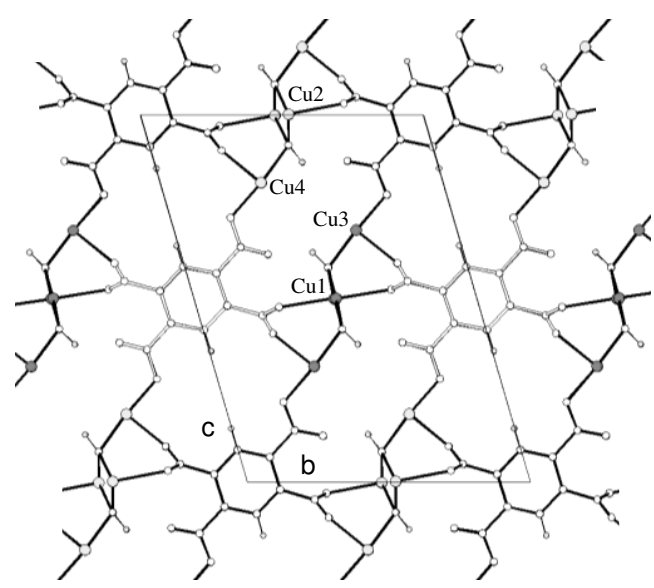

Figure 3. The connection between anions II and III and $\mathrm{Cu}^{2+}$ cations (open bonds for anion III).

Table 2. Bond Lengths (pm) of the Benzene-1,2,4,5tetracarboxylate-anions and the Nonane-1,9-diammonium-cation

\begin{tabular}{llllll}
\hline Anion I & \multicolumn{7}{l}{} \\
\hline $\mathrm{C}_{(10)}-\mathrm{C}_{(15)}$ & $139.4(7)$ & $\mathrm{C}_{(10)}-\mathrm{C}_{(16)}$ & $151.2(7)$ & $\mathrm{O}_{(3)}-\mathrm{C}_{(17)}$ & $127.0(6)$ \\
$\mathrm{C}_{(10)}-\mathrm{C}_{(11)}$ & $139.7(7)$ & $\mathrm{C}_{(11}-\mathrm{C}_{(17)}$ & $151.2(7)$ & $\mathrm{O}_{(4)}-\mathrm{C}_{(17)}$ & $123.6(6)$ \\
$\mathrm{C}_{(11)}-\mathrm{C}_{(12)}$ & $139.7(7)$ & $\mathrm{C}_{(13)}-\mathrm{C}_{(18)}$ & $150.3(7)$ & $\mathrm{O}_{(5)}-\mathrm{C}_{(18)}$ & $124.8(6)$ \\
$\mathrm{C}_{(12)}-\mathrm{C}_{(13)}$ & $139.5(7)$ & $\mathrm{C}_{(14)}-\mathrm{C}_{(19)}$ & $151.1(7)$ & $\mathrm{O}_{(6)}-\mathrm{C}_{(18)}$ & $126.1(6)$ \\
$\mathrm{C}_{(13)}-\mathrm{C}_{(14)}$ & $140.0(7)$ & $\mathrm{O}_{(1)}-\mathrm{C}_{(16)}$ & $125.5(6)$ & $\mathrm{O}_{(7)}-\mathrm{C}_{(19)}$ & $126.7(6)$ \\
$\mathrm{C}_{(14)}-\mathrm{C}_{(15)}$ & $138.9(7)$ & $\mathrm{O}_{(2)}-\mathrm{C}_{(16)}$ & $125.7(6)$ & $\mathrm{O}_{(8)}-\mathrm{C}_{(19)}$ & $124.2(6)$ \\
\hline Anion II & & & & & \\
\hline $\mathrm{C}_{(20)}-\mathrm{C}_{(21)}$ & $140.8(7)$ & $\mathrm{C}_{(20)}-\mathrm{C}_{(23)}$ & $150.5(6)$ & $\mathrm{O}_{(10)}-\mathrm{C}_{(23)}$ & $122.2(6)$ \\
$\mathrm{C}_{(21)}-\mathrm{C}_{(22)}$ & $139.5(7)$ & $\mathrm{C}_{(21}-\mathrm{C}_{(24)}$ & $150.2(7)$ & $\mathrm{O}_{(11)}-\mathrm{C}_{(24)}$ & $124.3(6)$ \\
$\mathrm{C}_{(20)}-\mathrm{C}_{(22)}$ & $138.9(7)$ & $\mathrm{O}_{(9)}-\mathrm{C}_{(23)}$ & $129.4(6)$ & $\mathrm{O}_{(12)}-\mathrm{C}_{(24)}$ & $127.7(6)$
\end{tabular}

\begin{tabular}{llllll}
\hline Anion III & & & & & \\
\hline $\mathrm{C}_{(25)}-\mathrm{C}_{(27)}$ & $139.0(7)$ & $\mathrm{C}_{(25)}-\mathrm{C}_{(28)}$ & $151.0(7)$ & $\mathrm{O}_{(14)}-\mathrm{C}_{(28)}$ & $127.5(6)$ \\
$\mathrm{C}_{(26)}-\mathrm{C}_{(27)}$ & $138.7(7)$ & $\mathrm{C}_{(26)}-\mathrm{C}_{(29)}$ & $149.2(7)$ & $\mathrm{O}_{(15)}-\mathrm{C}_{(29)}$ & $129.3(6)$
\end{tabular}

$\mathrm{C}_{(26)}-\mathrm{C}_{(25)} \quad 141.5(7) \quad \mathrm{O}_{(13)}-\mathrm{C}_{(28)} \quad 124.1(6) \quad \mathrm{O}_{(16)}-\mathrm{C}_{(29)}$

$122.1(6)$

\begin{tabular}{llllll}
\hline \multicolumn{6}{l}{ Nonane-1,9-diammonium-cation } \\
\hline $\mathrm{N}_{(1)}-\mathrm{C}_{(1)}$ & $149.7(10)$ & $\mathrm{C}_{(3)}-\mathrm{C}_{(4)}$ & $153.9(11)$ & $\mathrm{C}_{(6)}-\mathrm{C}_{(7)}$ & $148.8(12)$ \\
$\mathrm{N}_{(2)}-\mathrm{C}_{(9)}$ & $148.4(11)$ & $\mathrm{C}_{(2)}-\mathrm{C}_{(3)}$ & $150.5(10)$ & $\mathrm{C}_{(7)}-\mathrm{C}_{(8)}$ & $151.5(11)$ \\
$\mathrm{C}_{(1)}-\mathrm{C}_{(2)}$ & $148.5(11)$ & $\mathrm{C}_{(4)}-\mathrm{C}_{(5)}$ & $146.1(11)$ & $\mathrm{C}_{(8)}-\mathrm{C}_{(9)}$ & $148.2(11)$ \\
$\mathrm{C}_{(2)}-\mathrm{C}_{(3)}$ & $150.5(10)$ & $\mathrm{C}_{(5)}-\mathrm{C}_{(6)}$ & $154.6(12)$ & & \\
\hline
\end{tabular}

If the connection between $\mathrm{Cu}^{2+}$ and anion $\mathrm{I}$ is considered alone a two-dimensionally infinite arrangement parallel to the ac-plane results (Fig. 2). The same holds true with $\mathrm{Cu}^{2+}$ and anions II and III with respect to the $b c$-plane (Fig. 3). Thus the monodentate coordination between the benzene1,2,4,5-tetracarboxylate anions and the $\mathrm{Cu}^{2+}$-cations forms a three-dimensional framework with large channel-like voids along [001] (Fig. 4 and 5). The square-like crossection of the channels has a diagonal of about $900 \mathrm{pm}$ with the vander-Waals radii [52] of the framework atoms taken into account. The channels accommodate water molecules not bound to $\mathrm{Cu}^{2+}$ and nonane-1,9-diammonium-cations compensating for the negative excess charge of the $\left\{\left(\mathrm{Cu}_{4}(\mathrm{OH})_{2}\left[\mathrm{C}_{6} \mathrm{H}_{2}(\mathrm{COO})_{4}\right]_{2}\right\}_{\mathrm{n}}^{2 \mathrm{n}-}\right.$ framework.

The skeleton of the nonane-1,9-diammonium-cation does not take a complete all-trans (antiperiplanar) conformation (Fig. 6a). The ammonium group N(1) is rotated away which leads to a gauche conformation as seen in the Newman projection along the $\mathrm{C}(2)-\mathrm{C}(1)$ bond in Fig. $6 \mathrm{~b}$. The $\mathrm{C}-\mathrm{N}$ bond lengths are 149.7(10) and 148.4(11) pm. The C-C bonds range from 146.1(11) pm to 154.6 (12) pm (Tab. 2). Such conformation was also found in e.g. nonane-1,9diammonium bis-triiodide iodine [53] and catena-[catena- $\mu$ (1,9-diaminononane)cadmium(II)tetra- $\mu$-cyanonickelate(II)] -o-xylene(2/1) [54]. Whereas in $\mathrm{NH}_{3}\left(\mathrm{CH}_{2}\right)_{9} \mathrm{NH}_{3}\left(\mathrm{TiNbO}_{5}\right)_{2}$ [55] and in nonane-1,9-diammonium-chloride chloroacetate -hydroxyacetic acid [56] the diammonium-cations appear in the all-trans configuration.

The crystal structure is similar to the structure of a $\mathrm{Cu}(\mathrm{II})$ benzene-1,2,4,5-tetracarboxylate templated by 1,6diaminohexane, which crystallized in the space group P2/c and exhibits also channels with a diagonal of approximately $900 \mathrm{pm}$ [47]. However, using 1,4-diaminobutane [41] or 1,3-diaminopropane [40] as template agent the $\mathrm{Cu}^{2+}$-cations and the $\left[\mathrm{C}_{6} \mathrm{H}_{2}(\mathrm{COO})_{4}\right]^{2-}$-anions build up different frameworks. In contrast to the nonane-1,9-diammoniumcations in the present structure the hexane-1,6-diammonium-, the butane-1,4-diammonium- and the propane-1,3diammonium-cations adopt an all-trans conformation. In the case here the framework obviously determines the conformation of the template. 


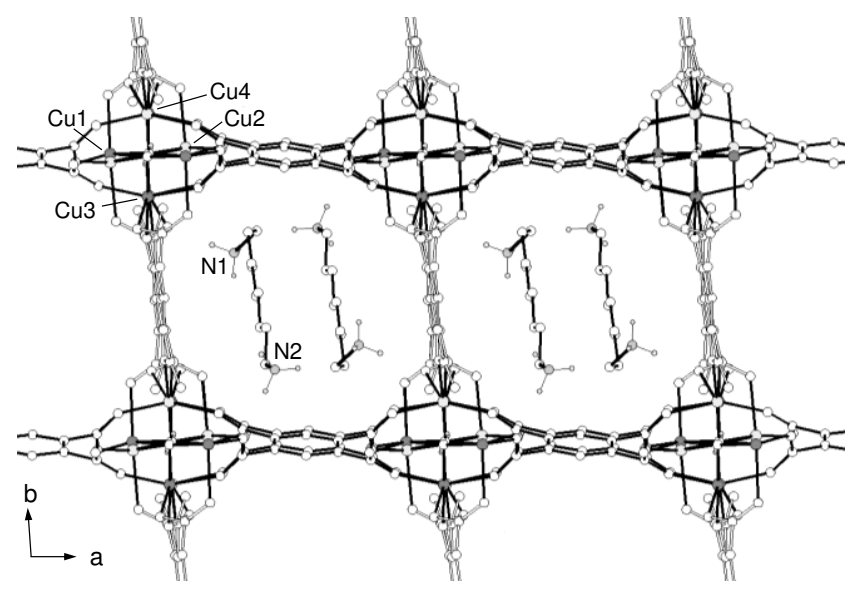

Figure 4. Crystal structure of $\mathrm{Cu}_{4}\left(\mathrm{H}_{3} \mathrm{~N}-\left(\mathrm{CH}_{2}\right)_{9-}\right.$ $\left.\mathrm{NH}_{3}\right)(\mathrm{OH})_{2}\left[\mathrm{C}_{6} \mathrm{H}_{2}(\mathrm{COO})_{4}\right]_{2} \cdot 5 \mathrm{H}_{2} \mathrm{O}$ viewed along [001] showing the square-like channels. Anions II and III are drawn with open bonds (guest water molecules are omitted).

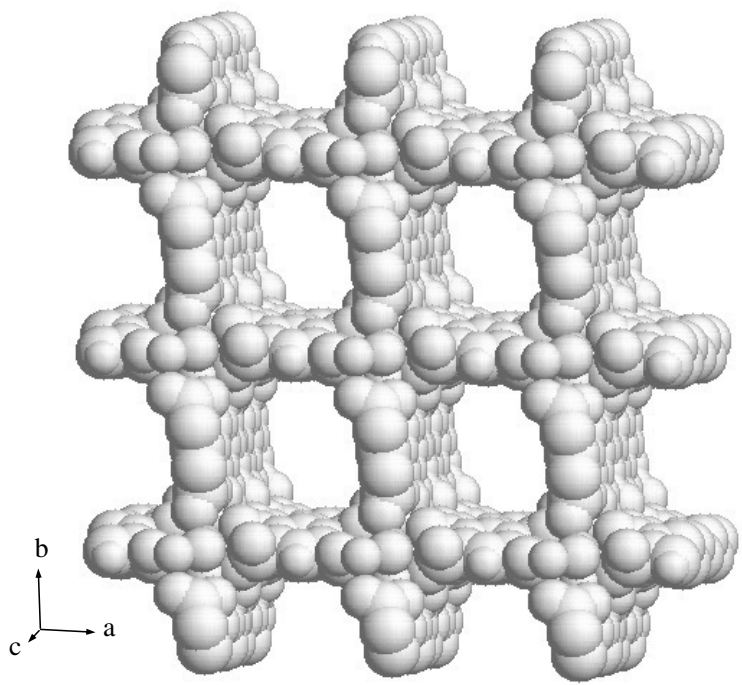

Figure 5. Space-filling model of the $\left\{\left(\mathrm{Cu}_{4}(\mathrm{OH})_{2}\left[\mathrm{C}_{6} \mathrm{H}_{2}(\mathrm{COO})_{4}\right]_{2}\right\}_{\mathrm{n}}{ }^{2 \mathrm{n}-}\right.$ framework.

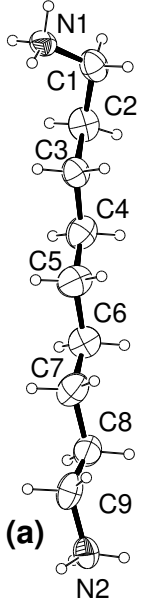

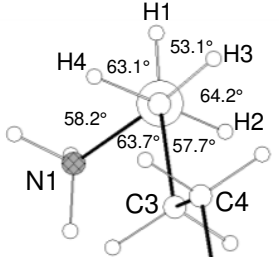

(b)
Figure 6. (a) The nonane-1,9-diammionium-cation (50 \% probability ellipsoids, arbitrary radii for hydrogen atoms). (b) Newman projection along the $\mathrm{C}(2)-\mathrm{C}(1)$ bond.

Table 3. Hydrogen bonds

\begin{tabular}{llll}
\hline $\mathrm{N} \cdots \mathrm{O}$ Distance (pm) & & & \\
\hline $\mathrm{N}_{(1)}-\mathrm{H}_{(23)} \cdots \mathrm{O}_{(\mathrm{w} 5)}$ & 288.1 & $\mathrm{~N}_{(2)}-\mathrm{H}_{(26)} \cdots \mathrm{O}_{(3)}$ & 296.0 \\
$\mathrm{~N}_{(1)}-\mathrm{H}_{(24)} \cdots \mathrm{O}_{(\mathrm{w} 1)}$ & 283.8 & $\mathrm{~N}_{(2)}-\mathrm{H}_{(27)} \cdots \mathrm{O}_{(\mathrm{w} 3)}$ & 287.6 \\
$\mathrm{~N}_{(1)}-\mathrm{H}_{(25)} \cdots \mathrm{O}_{(12)}$ & 276.8 & $\mathrm{~N}_{(2)}-\mathrm{H}_{(28)} \cdots \mathrm{O}_{(\mathrm{w} 4)}$ & 272.3 \\
\hline $\mathrm{O} \cdots \mathrm{O}$ Distance (pm) & & & \\
\hline $\mathrm{O}_{(\mathrm{w} 1)}-\mathrm{H}_{(31)} \cdots \mathrm{O}_{(\mathrm{w} 2)}$ & 276.4 & $\mathrm{O}_{(\mathrm{w} 3)}-\mathrm{H}_{(35)} \cdots \mathrm{O}_{(14)}$ & 271.6 \\
$\mathrm{O}_{(\mathrm{w} 1)}-\mathrm{H}_{(32)} \cdots \mathrm{O}_{(9)}$ & 289.9 & $\mathrm{O}_{(\mathrm{w} 3)}-\mathrm{H}_{(36)} \cdots \mathrm{O}_{(\mathrm{w} 1)}$ & 287.5 \\
$\mathrm{O}_{(\mathrm{w} 2)}-\mathrm{H}_{(33)} \cdots \mathrm{O}_{(7)}$ & 300.1 & $\mathrm{O}_{(\mathrm{w} 4)}-\mathrm{H}_{(38)} \cdots \mathrm{O}_{(13)}$ & 276.5 \\
$\mathrm{O}_{(\mathrm{w} 2)}-\mathrm{H}_{(34)} \cdots \mathrm{O}_{(11)}$ & 277.3 & $\mathrm{O}_{(\mathrm{w} 5)}-\mathrm{H}_{(39)} \cdots \mathrm{O}_{(\mathrm{w} 3)}$ & 288.2 \\
& & $\mathrm{O}_{(\mathrm{w} 5)}-\mathrm{H}_{(40)} \cdots \mathrm{O}_{(8)}$ & 308.7
\end{tabular}

The water molecules are not connected to $\mathrm{Cu}^{2+}$ and form hydrogen bonds to carboxylate oxygen atoms. However, not all carboxylate oxygen atoms are involved in hydrogen bonds. Surprisingly the carboxylate oxygen atoms $(\mathrm{O}(10)$ and $\mathrm{O}(16))$, which are not coordinated to $\mathrm{Cu}^{2+}$ do not appear in hydrogen bonds. This is a rather uncommon feature and is obviously accountable for the thermal stability of the dehydrated sample, as the uncoordinated carboxylate atoms do not suffer from structural destabilization by the cleavage of hydrogen bonds during the dehydration process. The water molecules $\mathrm{O}(\mathrm{w} 1), \mathrm{O}(\mathrm{w} 2), \mathrm{O}(\mathrm{w} 3)$ and $\mathrm{O}(\mathrm{w} 5)$ are linked together by hydrogen bonds. The nonane-1,9diammonium-cation forms hydrogen bonds to the carboxylate oxygen atoms $\mathrm{O}(3)$ of anion $\mathrm{I}$ and $\mathrm{O}(12)$ of anion II and links the $a c$ - and $b c$-plane of the $\left\{\left(\mathrm{Cu}_{4}(\mathrm{OH})_{2}\left[\mathrm{C}_{6} \mathrm{H}_{2}(\mathrm{COO})_{4}\right]_{2}\right\}_{\mathrm{n}}{ }^{2 \mathrm{n}-}\right.$ framework. Additionally, except of $\mathrm{O}(\mathrm{w} 2)$ the diammonium-cation acts as proton donator to the water molecules (Tab. 3).

In the coordination polymer $\mathrm{Cu}_{2}\left(\mathrm{H}_{3} \mathrm{~N}-\left(\mathrm{CH}_{2}\right)_{6-}\right.$ $\left.\mathrm{NH}_{3}\right)_{0.5}(\mathrm{OH})\left[\mathrm{C}_{6} \mathrm{H}_{2}(\mathrm{COO})_{4}\right] \cdot 3 \mathrm{H}_{2} \mathrm{O}$ [47] in contrast to this the hydroxo groups and the carboxylate oxygen atoms, which are not connected to any $\mathrm{Cu}^{2+}$-cations, are involved in strong hydrogen bonds. Moreover, the hexane-1,6-diammoniumcation forms only a hydrogen bond to the $\left[\mathrm{C}_{6} \mathrm{H}_{2}(\mathrm{COO})_{4}\right]^{4-}$ anion in the $a c$-plane.

TGA/DTA studies (Fig. 7) were carried out in air from room temperature to $1000{ }^{\circ} \mathrm{C}$ at a heating rate of $10 \mathrm{~K} / \mathrm{min}$. An endothermic weight loss between 90 and $170{ }^{\circ} \mathrm{C}$ of $8.5 \%$ corresponds to the loss of all water molecules. (calc. 8.7\%). The dehydrated sample was stable up to $260{ }^{\circ} \mathrm{C}$. The complete decomposition process is finished at about $520^{\circ} \mathrm{C}$. The total weight loss is $69.0 \%$ (calc. $69.4 \%$ ). The residue contained $\mathrm{CuO}$ and small amounts of $\mathrm{Cu}_{2} \mathrm{O}$ which were identified by X-ray powder diffraction.

In $\mathrm{Cu}_{2}\left(\mathrm{H}_{3} \mathrm{~N}-\left(\mathrm{CH}_{2}\right)_{6}-\mathrm{NH}_{3}\right)_{0.5}(\mathrm{OH})\left[\mathrm{C}_{6} \mathrm{H}_{2}(\mathrm{COO})_{4}\right] \cdot 3 \mathrm{H}_{2} \mathrm{O}$ [47] it turned out that the dehydrated sample is not thermally stable resulting in a continuous decomposition of the compound. The difference in the thermal behaviour between the present coordination polymer $\mathrm{Cu}_{4}\left(\mathrm{H}_{3} \mathrm{~N}-\left(\mathrm{CH}_{2}\right)_{9^{-}}\right.$ $\left.\mathrm{NH}_{3}\right)(\mathrm{OH})_{2}\left[\mathrm{C}_{6} \mathrm{H}_{2}(\mathrm{COO})_{4}\right]_{2} \cdot 5 \mathrm{H}_{2} \mathrm{O}$ and $\mathrm{Cu}_{2}\left(\mathrm{H}_{3} \mathrm{~N}-\left(\mathrm{CH}_{2}\right)_{6}-\right.$ $\left.\mathrm{NH}_{3}\right)_{0.5}(\mathrm{OH})\left[\mathrm{C}_{6} \mathrm{H}_{2}(\mathrm{COO})_{4}\right] \cdot 3 \mathrm{H}_{2} \mathrm{O}$ can mainly be explained by the different hydrogen bonding modes. 


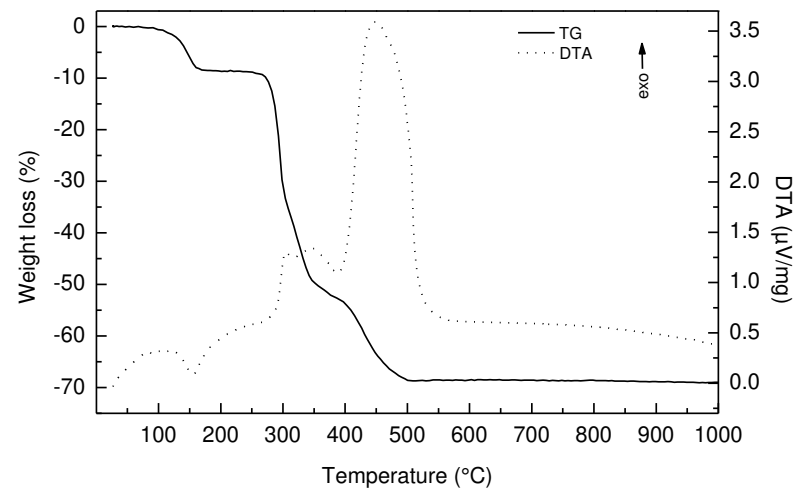

Fig. 7: Thermal analysis of $\mathrm{Cu}_{4}\left(\mathrm{H}_{3} \mathrm{~N}-\left(\mathrm{CH}_{2}\right)_{9^{-}}\right.$ $\left.\mathrm{NH}_{3}\right)(\mathrm{OH})_{2}\left[\mathrm{C}_{6} \mathrm{H}_{2}(\mathrm{COO})_{4}\right]_{2} \cdot 5 \mathrm{H}_{2} \mathrm{O}$.

The IR spectrum is shown in Fig. 8. O-H and $\mathrm{N}-\mathrm{H}$ stretching vibrations are in the range of 3000 to $3500 \mathrm{~cm}^{-1}$. Sharp bands at 2923 and $2853 \mathrm{~cm}^{-1}$ reflect C-H stretching modes. The symmetrical and asymmetrical stretching vibration of the carboxylate groups appear at 1582 and 1367 $\mathrm{cm}^{-1}$. The difference of $215 \mathrm{~cm}^{-1}$ indicates a monodentate coordination of the carboxylate groups [57]. The absorption band at $983 \mathrm{~cm}^{-1}$ is caused by the $\mathrm{Cu}-\mathrm{O}-\mathrm{H}$ bending mode [58].

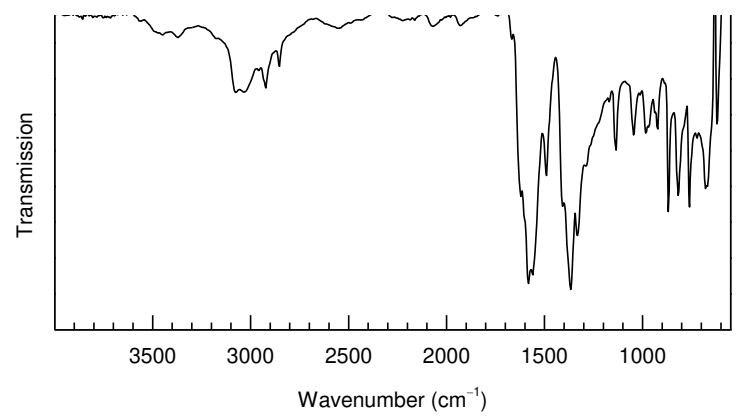

Fig. 8: IR spectrum of $\mathrm{Cu}_{4}\left(\mathrm{H}_{3} \mathrm{~N}-\left(\mathrm{CH}_{2}\right)_{9^{-}}\right.$ $\left.\mathrm{NH}_{3}\right)(\mathrm{OH})_{2}\left[\mathrm{C}_{6} \mathrm{H}_{2}(\mathrm{COO})_{4}\right]_{2} \cdot 5 \mathrm{H}_{2} \mathrm{O}$. interaction between the template ion and the framework, resulting in a gauche conformation of one of the $\mathrm{NH}_{3}{ }^{+}$ groups of the nonane-1,9-diammonium-cation. The template ion controls the formation and design of the framework and on the other hand the conformation of the template ion is simultaneously adapted to the framework.

\section{Experimental Section}

Single crystals of $\mathrm{Cu}_{4}\left(\mathrm{H}_{3} \mathrm{~N}-\left(\mathrm{CH}_{2}\right)_{9-}\right.$ $\left.\mathrm{NH}_{3}\right)(\mathrm{OH})_{2}\left[\mathrm{C}_{6} \mathrm{H}_{2}(\mathrm{COO})_{4}\right]_{2} \cdot 5 \mathrm{H}_{2} \mathrm{O}$ were synthesized in the presence of 1,9-diaminononane. An aqueous solution of $5 \mathrm{ml} 0.1 \mathrm{M} \mathrm{Cu}\left(\mathrm{NO}_{3}\right)_{2}$ was added to a solution of $5 \mathrm{ml} 0.2 \mathrm{M}$ 1,9-diaminononane. A precipitate, which appeared intermediately, was dissolved by addition of a small amount of $2 \mathrm{M} \mathrm{HNO}_{3}$. Then a solution of $5 \mathrm{ml}$ $0.05 \mathrm{M}$ sodium benzene-1,2,4,5-tetracarboxylate and $0.2 \mathrm{~g}$ urea were added. The resulting solution was heated at $80^{\circ} \mathrm{C}$ for 3 days in a drying oven yielding turquoise parallelepipeds.

Results of elemental analysis: (molecular weight 1038.79) C 33.58 (calc. 33.53); H 3.88 (4.09); N 2.70 (2.60)\%.

IR-ATR $\left(\mathrm{cm}^{-1}\right)$ : 3445(w), 3639(w), 3075(m), 3032(w), 2923(m), 2853(m), 1582(s), 1561(s), 1491(m), 1367(s), 1333(s), 1136(m), 1045(m), 983(m), 924(m), 867(m), 817(m), 761(m), 678(s), 620(m).

ATR Fourier transformed infrared (IR-ATR) measurements were carried out at room temperature using a Bio-rad FTS 25. Thermoanalytic measurements were performed in flowing air using a Netzsch STA429 device. X-ray single crystal structure determination was performed on a Siemens P4 four-circle diffractometer (MoK $\alpha$, graphite monochromator) in a theta range up to $25.00^{\circ}$. Numerical absorption corrections have been applied. The phase problem was solved by direct methods. Full matrix least squares refinement employing $|\mathrm{F}|^{2}$ made use of the SHELXTL program suite [59]. Some of the hydrogen atoms have been placed into calculated positions, further hydrogen atom positions could be taken from Difference Fourier maps. They were allowed to refine with different common isotropic displacement parameters. Crystallographic data are given in Table 4.

Further details concerning the crystal structure analysis have been deposited with Cambridge Crystallographic Data Centre, The Director, CCDC, 12 Union Road, Cambridge CB21EZ, UK, Fax +(1223)336-033, e-mail data_request@ccdc.cam.ac.uk, www.ccdc.cam.ac.uk/data_request.cif under CCDC 992557.

\section{Conclusions}

In summary, we reported on the synthesis and crystal structures of a new $\mathrm{Cu}$ (II)-benzene-1,2,4,5-tetracarboxylate in the presence of 1,9-diaminononane as template agent. The connection between the $\mathrm{Cu}^{2+}$-ions and the benzene-1,2,4,5tetracarboxylate-anions leads to a three-dimensional framework with negative excess charge and channel-like voids. The voids accommodate nonane-1,9-diammoniumcations as counter ions and water molecules, which are not connected to $\mathrm{Cu}^{2+}$. The structure shows an interesting 
Table 4. Crystallographic Data

\begin{tabular}{|c|c|}
\hline Empirical formula & $\mathrm{C}_{29} \mathrm{H}_{40} \mathrm{~N}_{2} \mathrm{Cu}_{4} \mathrm{O}_{23}$ \\
\hline Crystal system & triclinic \\
\hline Space group & P-1 (no.2) \\
\hline \multirow[t]{6}{*}{ Lattice constants } & $\mathrm{a}=1057.5(2) \mathrm{pm}$ \\
\hline & $\mathrm{b}=1166.0(2) \mathrm{pm}$ \\
\hline & $\mathrm{c}=1576.7(2) \mathrm{pm}$ \\
\hline & $\alpha=106.080(10)^{\circ}$ \\
\hline & $\beta=90.73(2)^{\circ}$ \\
\hline & $\gamma=94.050(10)^{\circ}$ \\
\hline Cell volume & $1.8624(5) \mathrm{nm}^{3}$ \\
\hline Formulas in unit cell & 2 \\
\hline Formula weight & $1038.79 \mathrm{~g} / \mathrm{mol}$ \\
\hline Density (calc.) & $1.852 \mathrm{~g} / \mathrm{cm}^{3}$ \\
\hline Wavelength & $71.073 \mathrm{pm}$ \\
\hline Absorption coefficient & $2.348 \mathrm{~mm}^{-1}$ \\
\hline Numerical absorption & $\min . /$ max. transmittance \\
\hline correction & $0.466 / 0.797$ \\
\hline Temperature & 293(2) K \\
\hline Crystal size (mm) & $0.10 \times 0.36 \times 0.50$ \\
\hline $\mathrm{F}(000)$ & 1056 \\
\hline$\Theta$-range & $2.32^{\circ}-25.00^{\circ}$ \\
\hline Limiting indices & h $0 /+12 ; \mathrm{k}-13 /+13 ; 1-18 /+18$ \\
\hline Reflections collected & 6850 \\
\hline Independent reflections & $6467\left(\mathrm{R}_{\mathrm{int}}=0.0165\right)$ \\
\hline Structure solution & Direct methods \\
\hline Structure refinement & Full-matrix least-squares on $|\mathrm{F}|^{2}$ \\
\hline Refined parameters & 582 \\
\hline Final mean shift/esd & 0.002 \\
\hline Goodness-of-fit on $|\mathrm{F}|^{2}$ & 1.307 \\
\hline Residuals (all data) & $\mathrm{R}_{1}=0.0544, \mathrm{w} \mathrm{R}_{2}=0.1093$ \\
\hline $\begin{array}{l}\text { Max. features in last } \\
\text { difference Fourier synthesis }\end{array}$ & 1076 and $-616 \mathrm{e} \cdot \mathrm{nm}^{-3}$ \\
\hline
\end{tabular}

\section{Acknowledgement}

We are grateful to Mrs Christina Apfel for recording the thermoanalytical data.

\section{References}

[1] G. Férey, Chem. Soc. Rev. 2008, 37, 191-214.

[2] L.-M. Zhao, H.-H. Li, Y. Wu, S.-Y. Zhang, Z.-J. Zhang, W. Shi, P. Cheng, D.-Z. Liao, S.-P. Yan, Eur. J. Inorg. Chem. 2010, 1983-1990.

[3] L. Karanovic, D. Poleti, G.A. Bogdanovic, A. Spasojevic-de Bire, Acta Cryst. 1999, C55, 911-913.

[4] D. Poleti and L. Karanovic, Acta Cryst. 1989, C45, 1716-1718.

[5] D. Poleti, D.R. Stojakovic, B. V. Prelesnik, R.M. Herak, Acta Cryst. 1988, C44, 242-245.

[6] M. Singh, D. Kumar, J. Thomas, A. Ramanan, J. Chem. Sci. 2010, 122, 757-769.

[7] S. Hentschel, Ph.D. Thesis, Univ. Munich 1993.

[8] B. Paul, B. Zimmermann, K.M. Fromm, C. Janiak, Z. Anorg. Allg. Chem. 2004, 630, 1650-1654.
[9] P. Lightfoot and A. Snedden, J. Chem. Soc., Dalton Trans. 1999, 3549-3551.

[10] J. Zhong-Sheng, D. Zhi-Bang, W. Ge-Cheng, N. Jia-Zhan, Jiegou Hиахие (J. Struct. Chem.) 1990, 9, 69-72.

[11] Z. Zhang, L. Wojtas, M.J. Zaworotko, Cryst. Growth Des. 2011, 11, 1441-1445.

[12] O.M. Yaghi, M. O'Keeffe, N.W. Ockwig, H.K. Chae, M. Eddaoudi, J. Kim, Nature 2003, 423, 705-714.

[13] C. Robl, Mat. Res. Bull. 1992, 27, 99-107.

[14] J.-P. Geng, Z.-X. Wang, X. He, H.-P. Xiao, M.-X. Li, Inorg. Chem. Comm. 2011, 14, 997-1000.

[15] Y.-Y. Jia, B. Chen, Y.-X. Yuan, Acta Cryst. 2012, E68, m1150.

[16] J.-C. Yao, Y.-F. Wang, L. Zhang, J.-B. Guo, X.-X. Cao, C.P. Fan, Chinese J. Struct. Chem. 2011, 30, 170-175.

[17] P. Cancino, E. Spodine, V. Paredes-Garcia, D. VenegasYazigi, A. Vega, Acta Cryst. 2013, C69, 1344-1347.

[18] E. Suresh, K. Boopalan, R.V. Jasra, M.M. Bhadbhade, Inorg. Chem. 2001, 40, 4078-4080.

[19] J. Zhang, Z. J. Li, X. Y. Cao, Y. G. Yao, J. Mol. Struct. 2005 $750,39$.

[20] C. Ma, W. Wang, X. Zhang, C. Chen, Q. Liu, H. Zhu, D. Liao, L. Li, Eur. J. Inorg. Chem. 2004, 3522.

[21] C. Ma, W. Wang, X. Zhang, C. Chen, Q. Liu, H. Zhu, D. Liao, L. Li, Eur. J. Inorg. Chem. 2004, 3522-3532.

[22] R. Köferstein and C. Robl, Z. Anorg. Allg. Chem. 2005, 631 , $1756-1758$

[23] R. Murugavel, D. Krishnamurthy, M. Sathiyendiran, J. Chem. Soc., Dalton Trans. 2002, 34-39.

[24] P.J. Hagrman, D. Hagrman, J. Zubieta, Angew. Chem. 1999, $111,2789-2848$.

[25] M. Rafizadeh, V. Amani, S. Zahiri, Acta Cryst. 2007, E63 m1938.

[26] R. Köferstein and C. Robl, Z. Anorg. Allg. Chem. 2007, 633, $1323-1325$

[27] A. Majumder, V. Gramlich, G.M. Rosair, S.R. Batten, J.D. Masuda, M.S. El Fallah, J. Ribas, J.-P. Sutter, C. Desplanches, S. Mitra, Cryst. Growth Des. 2006, 6, 2355-2368.

[28] R. Köferstein and C. Robl, Z. Anorg. Allg. Chem. 2004, 630, $185-188$.

[29] M. Rafizadeh and F. Manteghi, Acta Cryst. 2009, E65, m17.

[30] X. Bu, P. Feng, G.D. Stucky, Science 1997, 278, 2080-2085.

[31] S. Decurtins, H.W. Schmalle, P. Schneuwly, H.R. Oswald, Inorg. Chem. 1993, 32, 1888-1892.

[32] R. Vaidhyanathan, S. Natarajan, A.K. Cheetham, C. Rao, Chem. Mater. 1999, 11, 3636-3642.

[33] R. Vaidhyanathan, S. Natarajan, C. Rao, Chem. Mater. 2001, 13, 185-191.

[34] R. Köferstein and C. Robl, Z. Anorg. Allg. Chem. 2003, 629, $2186-2189$.

[35] S.S. Massoud, F.A. Mautner, F.R. Louka, S. Demeshko, S. Dechert, F. Meyer, Inorg. Chim. Acta 2011, 370, 435-443.

[36] Y.Y. Karabach, A.M. Kirillov, M. Haukka, J. Sanchiz, M.N. Kopylovich, A.J.L. Pombeiro, Cryst. Growth Des. 2008, 8, 4100-4108.

[37] E.-C Yang, Z.-Y. Liu, Z.-Y. Liu, L.-N. Zhao, X.-J. Zhao, Dalton Trans. 2010, 39, 8868-8871.

[38] H. Lin, H. Hu, X. Wang, B. Mu, J. Li, J. Coord. Chem. 2010, $63,1295-1303$ 
[39] R. Cao, Q. Shi, D. Sun, M. Hong, W. Bi, Y. Zhao, Inorg. Chem. 2002, 41, 6161-6168.

[40] D. Poleti, L. Karanovic, J. Serb. Chem. Soc. 2005, 70, 1441-1450.

[41] R. Köferstein and C. Robl, Z. Anorg. Allg. Chem. 2003, 629, 1374-1378.

[42] J.E. Mizzi, R.L. LaDuca, Inorg. Chim. Acta 2014, 411, 188198

[43] K. Brown, S. Zolezzi, P. Aguirre, D. Venegas-Yazigi, V. Paredes-Garcia, R. Baggio, M. A. Novak, E. Spodine, Dalton Trans. 2009, 1422-1427.

[44] L. Alaerts, E. Séguin, H. Poelman, F. Thibault-Starzyk, P.A. Jacobs, D.E. De Vos, Chem. Eur. J. 2006, 12, 7353-7363.

[45] Y.Y. Karabach, A.M. Kirillov, M. Haukka, M.N. Kopylovich, A.J.L. Pombeiro, J. Inorg. Biochem. 2008, 102, 1190-1194.

[46] S. Marx, W. Kleist, A. Baiker, J. Catal. 2011, 281, 76-87.

[47] R. Köferstein and C. Robl, Z. Anorg. Allg. Chem. 2014, 640, 310-316.

[48] I. Mihalcea, N. Henry, C. Volkringer, T. Loiseau, Cryst. Growth Des. 2012, 12, 526-535.

[49] M. Trömel, Acta Cryst. 1983, B39, 664-669.

[50] M. Trömel, Acta Crys. 1984, B40, 338-442.

[51] R.-K. Chiang, N.-T. Chuang, C.-S. Wur, M.-F. Chong, C.-R. Lin, J. Solid State Chem. 2002, 166, 158-163.

[52] A. Bondi, J. Phys. Chem. 1964, 68, 441-451.

[53] G.J. Reiß and J.S. Engel, Z. Naturforsch. 2004, 59b, 1114-1117.

[54] M. Hashimoto, T. Kitazawa, T. Hasegawa, T. Iwamoto, J. Incl. Phenom. 1991, 11, 153-158.

[55] A. Gransin, M. M. Borel, B. Raveau, J. Solid State Chem. 1985, 60, 366-375.

[56] A. Paul and M. Kubicki, J. Chem. Crystallogr. 2011, 41, 703-707.

[57] G.B. Deacon and R.J. Phillips, Coord. Chem. Rev. 1980, 33, 227-250.

[58] K. Nakamoto, Infrared Spectra of Inorganic and Coordination Compounds, 4th ed., John Wiley \& Sons, New York 1986.

[59] G. M. Sheldrick, Acta Cryst. 2008, A64, 112-122.

Received: ((will be filled in by the editorial staff)) Published online: ((will be filled in by the editorial staff)) 


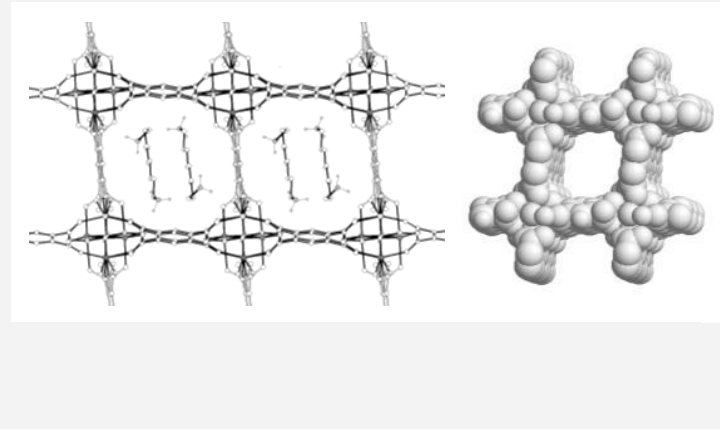

Roberto Köferstein and Christian Robl*

Page No. - Page No.

Synthesis, Crystal Structure, Hydrogen Bonding and Thermal

Behaviour of a Three-Dimensional Cu(II)-benzene-1,2,4,5-

tetracarboxylate Templated by 1,9-Diaminononane

$\mathrm{Cu}$ (II)-benzene-1,2,4,5-tetracarboxylate with 1,9-diaminononane

as template agent has been synthesized and structurally characterized. The three-dimensional framework shows large channel-like voids accommodating water molecules and nonane-1,9-diammoniumcations. 